\title{
In memoriam Antonio Fernando Catelli Infantosi (1947-2016)
}

\author{
Prof. Jurandir Nadal \\ Biomedical Engineering Program, COPPE / UFRJ, Rio de Janeiro, RJ, Brazil
}

Dear SBEB members and RBE community,

As a close colleague along his career, but mostly as a friend, I felt honored when I was invited to write a tribute to Fernando Infantosi, who has recently passed away. Although these words may bring back different memories to his friends, I consider they should be read especially by those who did not know him. It is an opportunity to witness a life dedicated to noble causes, no matter how ephemeral it was.

As a biomedical engineering professional, Infantosi's career blends with the history of our Brazilian Society of Biomedical Engineering, SBEB. Fernando started his studies in Biomedical Engineering in 1972, as a Master's student in the Biomedical Engineering Program, at UFRJ (Universidade Federal do Rio de Janeiro, Brazil). He took active part in the organization of the first three Brazilian Conferences on Biomedical Engineering (CBEB) and in the first steps towards the foundation of SBEB, during III CBEB, in 1975. In the same period, he became a lecturer at UFRJ and received the Master's Degree. Then, as a founding SBEB member, he acted as its treasurer along four years (75-79) and took the mission to preside the Society for the next two years (79-81). In 1981, Infantosi organized and presided the VII CBEB, held in Petropolis (RJ/Brazil), when the General Assembly of SBEB decided for the creation of a new scientific journal, named Revista Brasileira de Engenharia - Caderno de Engenharia Biomédica (RBE-CEB). Right after that, he moved to London for his PhD studies (82-86) at the Imperial College of Science, Technology and Medicine. This period represented the only gap in his active participation in SBEB.

In 1987, soon after his return to our country, the X CBEB was again held in Rio de Janeiro, at the Copacabana Palace Hotel. I remember Fernando helping in reviews, preparing the proceedings, and involved in several financial details during the conference. I was at that time the SBEB Treasurer. However, compared to him, I became just an actor in the background! During this Congress, the General Assembly approved a proposal made by UFRJ members to host, in Rio de Janeiro, the World Congress on Medical Physics and Biomedical Engineering, a tri-annual event promoted by the International Federations IOMP, IFMBE and IUPESM. The application for the RIO'94 World Congress was presented in the 1988 event in San Antonio, USA. Fernando was there, along with samba school dancers and samples of Brazilian coffee. They won! In 1991, we joined the delegation that went to Kyoto to confirm the nomination. Pleasant days in a wonderful city!

The RIO'94 World Congress was a great event, with about 2000 communications and the same number of participants. Fernando chaired the Finance Committee. Even while very busy as the Director of the COPPE Institute at UFRJ, he contributed a lot, together with the Conference Presidents, on finance uptake and control. After 20 years of existence, with almost no money to sustain itself, SBEB closed this congress with a small fortune! From then on, my friend Fernando became a tenacious advocate of this heritage. He was elected President of SBEB for two more terms (94-96; 2000-2002), Vice-President (96-98), and always tried to monitor and influence the Society actions.

Fernando played a fundamental role in the development of the Revista Brasileira de Engenharia Biomédica (RBEB - Brazilian Journal of Biomedical Engineering), which followed RBE-CEB and recently became the international Research on Biomedical Engineering journal. From 1994 on, along the 11 years I acted as RBEB Editor-in-chief, he was the primary supporter, taking particular care of the free distribution of the Journal, in order to reach all libraries in Latin America. Also notable was his effort to strengthen the Brazilian role in international scenario. He was a member of Administrative Committees, first in the IFMBE, then in the IUPESM, for about 20 years. His management inside these Federations was fundamental for strengthening CORAL (The Regional Council of Biomedical Engineering for Latin America), which went on to promote 
CLAEB (Latin American Congress of Biomedical Engineering) as an official event of IFMBE. Along the same line, Fernando was Vice-President (1998-2001), President (2001-2004) and Past-President (2004-2007) of CORAL, with active participation in the first four CLAEB, in Mazatlán (1998), Havana (2001), João Pessoa (2004) and Isla Margarita (2007). After João Pessoa, he arranged to have CLAEB Proceedings included into Springer IFMBE Proceedings series.

The only time I saw him saying "no" to an important invitation related to Biomedical Engineering was when probed for running for the IFMBE Presidency. I remember myself encouraging him to take upon this new challenge, since this would "crown" his enormous contribution to Biomedical Engineering. Completely unnecessary, I concluded! His contributions surely position him as one of the main pillars of the Brazilian biomedical engineering, without demerit of others.

His academic career was equally very successful. Fernando worked at UFRJ since 1974, as Biomedical Engineering Lecturer. Supervised by two eminent bioengineers Flavio Grynszpan (MSc) and Bruce McArthur Sayers $(\mathrm{PhD})$, he became an expert on biosignal processing, with particular emphasis on Neural Engineering, the main focus of his long career. He supervised more than 80 graduate researchers in Post-Doctorate, Doctorate and Master's degrees, as well as dozens of undergraduate students. Infantosi published more than 100 journal papers, 11 book chapters and about 400 conference papers, creating and disseminating knowledge throughout Brazil and beyond.

Fernando became a Full Professor in 1994, was Level 1A Researcher in CNPq and was awarded dozens of academic distinctions. He received a Recognition Diploma for his achievements in favor of Biomedical Engineering in Latin America, from the Senate of the Republic of Colombia, and the Giulio Massarani Prize from COPPE Institute (UFRJ) to acknowledge his academic merits, in 2009. From the 31 (!) papers he published in RBEB, three were winners as "best papers of the year" (1999, 2000 and 2012). He also supervised many finalists and winners of the CBEB Awards Candido Pinto de Melo and Young Investigator.

He was elected head of the department for three terms, and also Deputy Director (91-92) and Director of COPPE Institute (92-94) at UFRJ. Fernando was also a founder and Director of COPPETEC Foundation (92-94), Vice-President of José Bonifácio Foundation and assumed numerous representations inside UFRJ, SBEB and in various Brazilian Agencies. At the time he passed away, he was a member of three evaluation committees simultaneously: CNPq, CAPES and FAPERJ! He was also in the Editorial Boards of three top ranked Biomedical Engineering journals. That would be enough for most of us, but he was also managing the construction of a 3,000 $\mathrm{m}^{2}$ building for the Biomedical Engineering Program, and much more.

Last but not least, Infantosi was a magnificent person. He was a man with doctrines, principles, convictions, virtues, beliefs, passions, and friends. He fought for them all like no one, until his last day, as if giving to all subjects the highest priority. His main criticism was against individualism. I join his sons, Rodrigo and Rafael, as heirs of his work, his example and his generosity. He will remain alive in the memory of all of us. 